\title{
sciendo
}

\section{IMPACT OF DIETARY CORNSTARCH LEVELS ON GROWTH PERFORMANCE, BODY COMPOSITION AND DIGESTIVE ENZYME ACTIVITIES OF JUVENILE SOFT-SHELLED TURTLE (PELODISCUS SINENSIS)*}

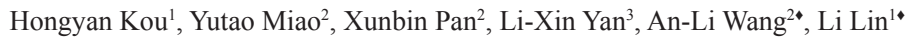

${ }^{1}$ Guangzhou Key Laboratory of Aquatic Animal Diseases and Waterfowl Breeding, Guangdong Provincial Key Laboratory of Waterfowl Healthy Breeding,

College of Animal Sciences and Technology, Zhongkai University of Agriculture and Engineering, Guangzhou, Guangdong, 510225, China

${ }^{2}$ Key Laboratory of Ecology and Environment Science in Guangdong Higher Education, Guangdong Provincial Key Laboratory for Healthy and Safe Aquaculture, College of Life Science, South China Normal University, Guangzhou 510631, People's Republic of China ${ }^{3}$ Guangzhou Feed Research Institute, Guangzhou 510670, People's Republic of China •Corresponding authors: anliwang12@yeah.net; linli@zhku.edu.cn

\begin{abstract}
We conducted an 8-week feeding trial to determine the effects of dietary starch levels on growth performance, body composition, and digestive enzyme activities of juvenile soft-shelled turtles. Six fish meal-based diets containing $120,180,240,300,360$ and $420 \mathrm{~g} \mathrm{~kg}^{-1}$ cornstarch were formulated. Body weight gain (BWG), crude protein concentration in whole body, as well as protease activity increased with increasing dietary starch levels until the highest at $240-300 \mathrm{~g} \mathrm{~kg}^{-1}$, but it was decreased at higher dietary starch content. In contrast, the feed conversion ratio, moisture content and hepatosomatic index were the lowest at $240-300 \mathrm{~g} \mathrm{~kg}^{-1}$ of cornstarch. The weight gain correlated significantly with the survival rate, the crude protein composition and the protease activity, but correlated negatively to the moisture content and the hepatosomatic index. The optimal dietary starch levels for the maximum BWG and maximum protease activity were $267.25 \mathrm{~g} \mathrm{~kg}^{-1}$ and $266.79 \mathrm{~g} \mathrm{~kg}^{-1}$, respectively. The $\alpha$-amylase activity was the lowest at $120 \mathrm{~g} \cdot \mathrm{kg}^{-1}$ of cornstarch, and increased with increasing cornstrach content. The lipase activity and the amount of crude lipid in the turtles were not influenced by dietary cornstarch. Our results suggest that around $300 \mathrm{~g} \mathrm{~kg}^{-1}$ of cornstarch in diets is optimal for juvenile soft-shelled turtles.
\end{abstract}

Key words: soft-shelled turtle, Pelodiscus sinensis, growth performance, corn gluten, enzymatic activity, amylase activity

*This study was supported by the Scientific and Technological Planning Project Guangzhou (Grant No.: 2006Z3-E0291) and the Scientific and Technological Planning Project of Guangdong Province (Grant No.: 2009A020101006) to A-L Wang. 
Soft-shelled turtle ( $P$. sinensis) has become a high-valued commercial aquatic animal due to nutritional properties, meat quality, elegant taste and medicinal function (Shao, 2012). It is now cultivated as a commercial species as food or medicine across many Asian countries, including China, Korea, Japan, northern Vietnam and much of southeastern Asia, and has been introduced to Hawaii and Guam Asia countries (Lei, 2006). In China alone, the annual production was estimated to be $>300$ million in 2008 and 340,000 tons (estimated 1 billion specimens) currently, forming a multi-billion dollar industry (Gong et al., 2018; Haitao et al., 2008). Traditionally, it is considered a medicinal cuisine due to its high nutritional value, with abundant collagen and unsaturated fatty acids (Wang et al., 2013). It is a good source of protein, high in calcium, and rich in vitamins, phosphorous and zinc (Shao, 2012). The long-term administration of soft-shelled turtle powder was found to attenuate fatigue, accelerate recovery from stress in mice and reduce the development of hypertension in rats (Feng et al., 1996), In addition, the eggs of soft-shelled turtles could antagonize the formation of advanced glycation end-products (AGEs), key players in the pathogenesis of diabetes, atherosclerosis, chronic renal failure and Alzheimer's disease (Yamanaka et al., 2016). Thus, soft-shelled turtle has become a highly valuable food source and its culture has become a central research issue. In particular, the active ingredient Chinese soft-shelled turtle hydrolysate $(\mathrm{CTH})$ was found to possesses potent antihypertensive and antioxidant activity, as well as an inhibitory effect on AGEs (Liu et al., 2012).

The production of $P$. sinensis underwent the transit from the wild to farming in the early 1990s. At the beginning stage (until mid 1990s), the culture technology was mainly indoor and dependent on the warm temperature of $28^{\circ} \mathrm{C}-32^{\circ} \mathrm{C}$ and the feeding of high quality eel feeds in replacement of trash fish. Thereafter, the outdoor culture with improved feeding regimes developed rapidly and greatly increased the turtle production (Shao, 2012). One essential aspect of production is the feeding technology based on numerous studies investigating dietary components and their dietary level, such as proteins, lipid, trace elements, vitamins and amino acids, etc (Chu et al., 2007; Huang and Lin, 2002; Huang et al., 2005; Lin and Huang, 2007; Rawski et al., 2018; Wu and Huang, 2008; Zhou F. et al., 2013; Zhou et al., 2004). The essential nutrients in turtle diets are crude protein $(39.0-46.5 \%)$, crude fat $(8.8 \%)$, Ca $(5.7 \%)$, P (3.0\%), methionine (1.03\%), and cysteine $(0.25 \%)$ (Rawski et al., 2018).

There have been constant attempts to improve the feeding of aquaculture animals in consideration of growth and economical issues. For example, the cold-pressed rape cake (CPRC) has been investigated to partially substitute dietary proteins for common carp (Mazurkiewicz et al., 2011); and starch has been introduced to substitute for monosaccharides as an inexpensive source of energy in aquaculture feed. A number of studies have focused on the roles of starch in the feeding of fish and shrimp (Enes et al., 2006; Tran-Duy et al., 2008; Xiao et al., 2014). However, there has been no report on the effects of dietary starch levels on growth performance, body composition and digestion of soft-shelled turtles (Rawski et al., 2018).

The feed for turtles is in the form of dough, so it is easy to make the aquaculture water dirty. The use of binders, such as starch, can significantly improve water stabil- 
ity of feeds, with the minimum starch content of 18 to $22 \mathrm{~g} / \mathrm{kg}^{-1}$ and 9 to $11 \mathrm{~g} \mathrm{~kg}^{-1}$ for floating and sinking pellets, respectively (Solomon et al., 2011). It is easy to disperse feed in water if the inclusion of starch in the feed is too low. Therefore, the function of starch in the feed is critical (Kannadhason et al., 2009; Riaz, 1997).

In the current study, we hypothesized that the levels of dietary cornstarch may significantly impact the growth of soft-shelled turtles, and present solid data showing that certain amount of cornstarch in the feeding could produce the best growth performance in $P$. sinensis. In addition, it has been shown that digestive enzymes like protease, alpha-amylase and lipase could respond to dietary starch and may mediate the effects of the dietary carbohydrates on growth performance in aquatic animals (Kawai and Ikeda, 1972; Ren et al., 2011). Thus we also examined the changes of these digestive enzymes in relation to the dietary cornstarch levels. Here we present the analysis of the relationship of the enzymatic changes to the effect of dietary cornstarch levels on the growth performance of $P$. sinensis.

\section{Material and methods}

\section{Animals}

Soft-shelled turtles were obtained from a commercial farm in Guangzhou, China. All animal experiments were approved by the ethics committee of the University (ZK2013108).

\section{Experimental diets}

Ingredients were ground and filtered into fine powder through a $200-\mu \mathrm{m}$ mesh. All the ingredients were weighed and mixed thoroughly in a mixer. Then the diets were sealed in plastic bags and stored at $-20^{\circ} \mathrm{C}$. Six experimental diets containing $120,180,240,300,360$ and $420 \mathrm{~g} \mathrm{~kg}^{-1}$ cornstarch were formulated as in Table 1. When feeding the soft-shelled turtles, the diets and water were mixed in a ratio of $1: 1$ to form dough.

\section{Feeding trial}

At the beginning of the experiment, turtles were fasted for $24 \mathrm{~h}$ and weighed. The average initial weight of the turtles was $5.68 \pm 0.08 \mathrm{~g}$. A total of 480 turtles were used, they were randomly distributed into 24 plastic tanks $(30 \mathrm{~cm} \times 18 \mathrm{~cm}$ $\times 22 \mathrm{~cm}$ ) with 20 turtles per tank. The experimental design included 6 dietary treatments, each diet was assigned to four replicated tanks. Turtles were fed to apparent satiation twice (9:00 and 17:00) a day for 8 weeks. During the feeding period, rearing temperature was kept at $26 \pm 2{ }^{\circ} \mathrm{C}$ and $\mathrm{pH}$ 8.1. Uneaten feed was collected, dried and weighed, and deducted from the total feed for calculation of feed conversion ratio. Feces were collected daily in the morning and afternoon before feeding. The uneaten food was collected within 1 hour of feeding, and was filtered through a fine sieve to remove feces and ensure the collected uneaten food was free of excrement. 
Table 1. Feed formulation and proximate analysis of diets $\left(\mathrm{g} \mathrm{kg}^{-1}\right.$ dry matter)

\begin{tabular}{|c|c|c|c|c|c|c|}
\hline Ingredients & \multicolumn{6}{|c|}{ Amount of ingredients $\left(\mathrm{g} \mathrm{kg}^{-1}\right)$} \\
\hline White fishmeal & 450 & 450 & 450 & 450 & 450 & 450 \\
\hline Cornstarch & 120 & 180 & 240 & 300 & 360 & 420 \\
\hline Yeast & 10 & 10 & 10 & 10 & 20 & 20 \\
\hline $\mathrm{Ca}\left(\mathrm{H}_{2} \mathrm{PO}_{4}\right)_{2}$ & 17 & 17 & 17 & 17 & 17 & 17 \\
\hline Cellulose & 70 & 50 & 40 & 30 & 10 & 10 \\
\hline Wheat flour & 280 & 240 & 190 & 140 & 90 & 30 \\
\hline Choline (50\%) & 2 & 2 & 2 & 2 & 2 & 2 \\
\hline Corn oil & 40 & 40 & 40 & 40 & 40 & 40 \\
\hline Mineral premix & 8 & 8 & 8 & 8 & 8 & 8 \\
\hline Vitamin premix & 3 & 3 & 3 & 3 & 3 & 3 \\
\hline \multicolumn{7}{|c|}{ Proximate analysis ( $\mathrm{g} \mathrm{kg}^{-1}$ dry matter $)$} \\
\hline crude protein & 338.7 & 335.2 & 331 & 326.3 & 327.2 & 321.4 \\
\hline crude lipid & 82.3 & 82.5 & 83 & 82.70 & 82.8 & 83.1 \\
\hline crude fiber & 79.15 & 59.28 & 48.73 & 37.25 & 26.39 & 20.59 \\
\hline crude ash & 68.9 & 70.1 & 69.2 & 69.7 & 69.8 & 69.9 \\
\hline NFE & 430.95 & 452.92 & 468.07 & 484.05 & 493.81 & 505.01 \\
\hline GE & 20.05 & 19.97 & 20.06 & 20.01 & 19.95 & 19.92 \\
\hline
\end{tabular}

Minerals for mineral premix and vitamins for vitamin premix: Haid Feeds Co., Ltd. (Guangzhou, PR China); white fishmeal: North pacific white fishmeal (American Seafoods Company, USA); cornstarch: Beijing Aogerun Science and Technology Co., Ltd (Beijing, China); yeast: Xuzhou SaiFu Biological Technology Co. Ltd (Xuzhou, Jiangsu, China); wheat flour: Luwang Group Co., Ltd. (Jining, Shandong Province, China); corn oil: COFCO (Tianjin, China); $\mathrm{Ca}\left(\mathrm{H}_{2} \mathrm{PO}_{4}\right)_{2}$ Lufeng Tianbao Phosphorus Chemical Co., Ltd (Lufeng County, Yunan Province, China); cellulose: Zouping LiCheng Chemical Co., Ltd. (Bingzhou, Shandong Province, China); choline (50\%): Changzhou Tianyuan Animal Husbandry CO., Ltd. (Changzhou, Hebei Province, China).

Crude fiber content in diets was determined by the F600 Fiber Analyzer (Jinan Hanon Instruments Co., Ltd. Shandong Province, China). NFE=100-(crude protein +crude lipid +ash + crude fiber). Gross energy was analyzed using an adiabatic bomb calorimeter (HWR-15E, Shangli Shanghai, China).

\section{Analysis and measurements}

\section{Sample collection}

After an 8-week feeding trial, the turtles were fasted for $24 \mathrm{~h}$ and sacrificed. The turtles were killed by decapitation after anesthesia with MS-222. The body weight of the turtles in each tank was measured. Livers were taken and then weighed to calculate the hepatosomatic index (HSI). Intestines of seven turtles from each tank were obtained and stored at $-80^{\circ} \mathrm{C}$ for further analysis. Three turtles in each tank were collected and stored at $-20^{\circ} \mathrm{C}$ to determine whole-body composition, including the proportions of moisture, crude protein, crude lipid and ash, respectively.

\section{Growth performance}

Growth performance was evaluated by survival rate $(\%), \mathrm{BWG}$, feed conversion ratio (FCR) and HSI. These parameters were calculated as follows (Mazurkiewicz et al., 2011): 
Survival rate $(\%)=100$ (Initial turtle number - Dead turtle number)/Initial turtle number.

$B W G(\%)=100$ (final weight - initial weight) $(\mathrm{g}) /$ initial weight $(\mathrm{g})$

$F C R=$ total feed intake $(g) /($ final body weight - initial body weight $)(g)$

HSI $(\%)=100$ (liver weight/body weight).

\section{Analysis of diets and whole-body proximate composition}

Proximate analysis of the diets and the turtles was performed using the standard methods (AOAC International Methods Committee, 2011). Moisture content of the turtles and diets was analyzed after drying at $105^{\circ} \mathrm{C}$ for $24 \mathrm{~h}$. Crude fat was tested through ether extraction. Crude protein was determined by measuring nitrogen $(\mathrm{N} \times$ 6.25) using the Kjeldahl method (Kjeltec 2300 Protein Analyzer, Denmark). Ash was determined by a muffle furnace at $550^{\circ} \mathrm{C}$ for $4 \mathrm{~h}$.

\section{Measurement of digestive enzyme activities}

Intestine samples were accurately weighed, then homogenized in ice-cold $0.75 \%$ saltwater in the proportion of 1:5 (w/v). Following centrifugation $(1800 \mathrm{~g}, 15 \mathrm{~min}$, $4^{\circ} \mathrm{C}$ ), the supernatants were removed and kept at $-20^{\circ} \mathrm{C}$ for analysis.

The determination of protease, amylase and lipase activities was performed similar to previous reports (Ren et al., 2011; Zou et al., 2011). Specifically, the protease (EC 3.4.21.1) was determined using the assay kit A080-3 (Nanjing Jiancheng Bioengineering Institute, Nanjing, China). In brief, $40 \mu \mathrm{l}$ sample was mixed with $0.2 \mathrm{ml}$ of reagents II, allowed to react for $10 \mathrm{~min}$ at $37^{\circ} \mathrm{C}$; and then added $0.4 \mathrm{ml}$ of reagent I and allowed to react for $10 \mathrm{~min}$ at $37^{\circ} \mathrm{C}$. After centrifuging at $3500 \mathrm{r} / \mathrm{min}$ for 10 minutes, the supernatant was taken for color display. The absorbance at $660 \mathrm{~nm}$ was detected using a 722 spectrophotometer (Sunny Optical Technology, Inc., Zhejiang, China). Protease activity was calculated as $\mathrm{U} / \mathrm{mg}$ protein.

The lipase activity of intestine was determined using the lipase detection kit A054 (Jiancheng Bioengineering Institute, Nanjing, China). In brief, the substrate buffer was mixed with $25 \mu \mathrm{L}$ tissue homogenate, supernatant was mixed with the pre-warmed substrate buffer and reagents, and the absorbance was quickly detected at $420 \mathrm{~nm}$ for $30 \mathrm{sec}$ (Value A1). The mixed solution was allowed to react for $10 \mathrm{~min}$ at $37^{\circ} \mathrm{C}$, and the absorbance was again quickly detected at $420 \mathrm{~nm}$ for $30 \mathrm{sec}$ (Value A2). The difference of absorbance A = A1-A2 was calculated. One unit of lipase activity was defined as the consumption of $1 \mu \mathrm{mol}$ substrate by 1 gram of tissue protein (reaction with the substrate for $10 \mathrm{~min}$ ).

Determination of protein concentration according to the method of Lowry et al. (1951), using bovine serum albumin as the standard.

Alpha-amylase (E.C. 3.2.1.1) activity of the tissue supernatants was measured using the C016 amylase assay kit (Jiancheng Bioengineering Institute, Nanjing, China). Briefly, the sample extract $(10 \mathrm{uL})$ was mixed with $0.5 \mathrm{~mL}$ of substrate buffer at $37^{\circ} \mathrm{C}$, and was allowed to react for $7.5 \mathrm{~min}$. The reaction was then stopped by adding $0.5 \mathrm{~mL}$ of iodine application solution. The absorbance at $660 \mathrm{~nm}$ was detected using a $722 \mathrm{spec}-$ trophotometer (Sunny Optical Technology, Inc., Zhejiang, China). The amylase activity was defined as hydrolysis of $1 \mathrm{mg}$ starch by $1 \mathrm{~g}$ tissue per minute at $37^{\circ} \mathrm{C}, \mathrm{pH} 7.0(\mathrm{U} / \mathrm{g})$. 


\section{Statistical analysis}

All data were analyzed by one-way analysis of variance (ANOVA) using the software SPSS 13.0 for Windows. Significant differences in the means between dietary treatments were evaluated by Tukey's multiple range tests. The optimum dietary cornstarch requirements based on BWG, protease activity and lipase activity were estimated using second-order polynomial regression analysis.

\section{Results}

\section{Growth performance}

Average BWG continuously and significantly increased at the $180(\mathrm{P}<0.05)$ and $240 \mathrm{~g} \mathrm{~kg}^{-1}(\mathrm{P}<0.01)$ dietary cornstarch, reached a plateau between 240 and $300 \mathrm{~g} \mathrm{~kg}^{-1}$ starch levels; but started to decrease at $360 \mathrm{~g} \mathrm{~kg}^{-1}(\mathrm{P}<0.05)$ and returned to the beginning level at $420 \mathrm{~g} \mathrm{~kg}^{-1}$ starch levels. Thus, BWG showed a significantly positive correlation with dietary cornstarch between the starch levels of 120 to $240 \mathrm{~g} \mathrm{~kg}^{-1}$. Overall, the change of BWG in relation to dietary starch levels presented a bell-shape curve. The relationship between BWG and dietary starch levels was expressed by a polynomial regression model $\left(y=-0.0022 x^{2}+1.1759 x-16.144\left[R^{2}=0.9038\right]\right.$; Figure 1). A secondary curve equation according to regression analysis of BWG against the dietary cornstarch levels indicated that the optimal dietary cornstarch level for maximum BWG was $267.25 \mathrm{~g} \mathrm{~kg}^{-1}$.

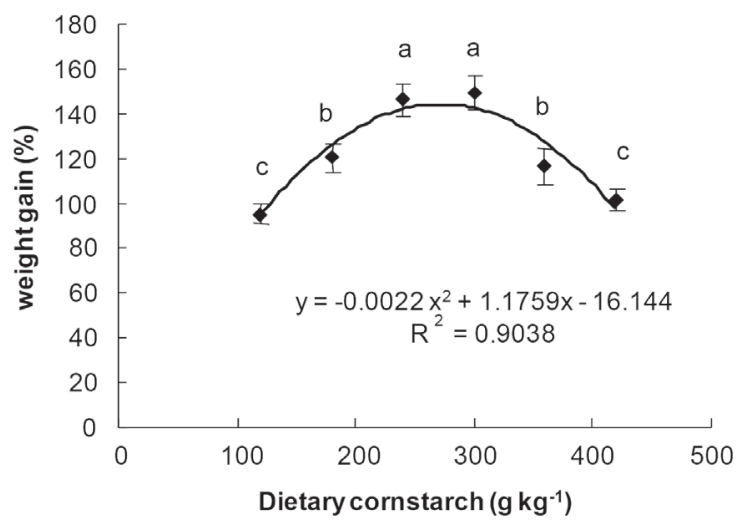

Figure 1. The relationship between BWG and dietary cornstarch. A polynomial regression model was obtained. The lower case letters above the columns indicate significant (between different letters) or non-significant (between same letters) statistical differences. Significance level: between $\mathrm{c}$ and $\mathrm{b}$ or $\mathrm{b}$ and a, $\mathrm{P}<0.05$; between $\mathrm{c}$ and a: $\mathrm{P}<0.01$

Survival rate and feed conversion ratio (FCR, feed consumed/BWG) are shown in Table 2. Significant differences were observed in survival rate amongst the turtles in the different treatment groups $\left(\mathrm{P}<0.05\right.$ at 180 and $360 \mathrm{~g} \mathrm{~kg}^{-1} ; \mathrm{P}<0.01$ at 240 and $300 \mathrm{~g} \mathrm{~kg}^{-1}$ ). Turtle survival rate was significantly higher at 240 and $300 \mathrm{~g} \mathrm{~kg}^{-1}$ of dietary starch with no significant difference at 180,360 and $420 \mathrm{~g} \mathrm{~kg}^{-1}$ of dietary starch. 
Table 2. Effects of different levels of dietary starch on the growth performance

\begin{tabular}{c|c|c|c|c|c|c}
\hline \multirow{2}{*}{ Parameters } & \multicolumn{7}{|c}{ Different levels of cornstarch $\left(\mathrm{g} \mathrm{kg}^{-1}\right)$} \\
\cline { 2 - 7 } & 120 & 180 & 240 & 300 & 360 & 420 \\
\hline
\end{tabular}

Survival rate $85.24 \pm 1.15$ b $88.31 \pm 0.87$ b $\quad 98.41 \pm 0.52$ a $100.00 \pm 0.00$ a $\quad 90.27 \pm 0.79$ b $\quad 84.46 \pm 1.25$ b (\%)

$\begin{array}{lllllll}\text { FCR } & 3.25 \pm 0.39 \mathrm{a} & 2.58 \pm 0.24 \mathrm{~b} & 1.86 \pm 0.23 \mathrm{c} & 1.75 \pm 0.26 \mathrm{c} & 2.01 \pm 0.32 \mathrm{bc} & 2.61 \pm 0.38 \mathrm{~b} \\ \text { PER } & 0.91 \pm 0.05 \mathrm{~d} & 1.15 \pm 0.08 \mathrm{c} & 1.54 \pm 0.09 \mathrm{~b} & 1.68 \pm 0.08 \mathrm{a} & 1.53 \pm 0.07 \mathrm{~b} & 1.16 \pm 0.09 \mathrm{c} \\ \text { SGR } & 1.20 \pm 0.03 \mathrm{c} & 1.42 \pm 0.03 \mathrm{~b} & 1.60 \pm 0.04 \mathrm{a} & 1.62 \pm 0.04 \mathrm{a} & 1.38 \pm 0.03 \mathrm{~b} & 1.24 \pm 0.02 \mathrm{c}\end{array}$

WGR (\%) $\quad 95.18 \pm 4.03$ c $120.16 \pm 6.08$ b $146.25 \pm 6.98$ a $149.17 \pm 7.38$ a $116.37 \pm 8.13$ a $101.48 \pm 5.23$ a

\begin{tabular}{|c|c|c|c|c|}
\hline FR (\%) & $3.75 \pm 0.21 \mathrm{a}$ & $3.47 \pm 0.23 \mathrm{a}$ & $2.82 \pm 0.14 \mathrm{~b}$ & $2.58 \pm 0.13 \mathrm{c}$ \\
\hline
\end{tabular}

FCR: feed conversion ratio; SGR: specific growth rate, FR: feeding rate; PER: protein efficiency ratio; WGR: weight gain rate. Values are presented as mean \pm S.E (four replications). Statistical significance $(\mathrm{P}<0.05)$ is indicated by small letters. Statistical significance, survival rate: $\mathrm{P}=0.026$; FCR: $\mathrm{P}=0.008$; $\mathrm{PER}$ : $\mathrm{P}<0.01$; SGR: $\mathrm{P}<0.01$; WGR: $\mathrm{P}<0.01$; FR: $\mathrm{P}<0.05$.

Methods of calculations: $P E R=g$ wet weight gain/g dry matter protein intake; $F R=200 F /\left[\left(W_{1}+W_{2}\right) n d\right]$, where "F" is the total food intake (g), " $\mathrm{n}$ " is the number of experimental individuals, "d" is the number of days of the experiment, $\mathrm{W}_{2}=$ final weight, $\mathrm{W}_{1}=$ initial weight; $\mathrm{SGR}=100 *\left(\mathrm{Ln} \mathrm{W}_{2}-\mathrm{LnW}_{1}\right) / \mathrm{d}, \mathrm{W}_{2}=$ final weight $\mathrm{W}_{1}=$ initial weight.

The FCR was significantly increased at 180, 240, 300 and $360 \mathrm{~g} \mathrm{~kg}^{-1}$, being highest at 240 and $360 \mathrm{~g} \mathrm{~kg}^{-1}(\mathrm{P}<0.01)$; but not significantly changed at $420 \mathrm{~g} \mathrm{~kg}^{-1}$ of starch. It changed in the opposite trend as the BWG.

The HSI changed in the similar trend as FCR in relation to dietary starch levels. It was significantly lower at $180(\mathrm{P}<0.05), 240$ and $360 \mathrm{~g} \mathrm{~kg}^{-1}$, was the lowest at 240 and $300 \mathrm{~g} \mathrm{~kg}^{-1}(\mathrm{P}<0.01)$, but with no significant change at $360 \mathrm{~g} \mathrm{~kg}^{-1}$ of dietary starch level (Figure 2).

\section{Whole-body composition}

The amount of crude protein (Table 3) differed significantly between the treatments, elevated with increasing dietary cornstarch levels up to $300 \mathrm{~g} \mathrm{~kg}^{-1}$, and declined at higher dietary cornstarch levels, being highest at $300 \mathrm{~g} \mathrm{~kg}^{-1}$ of dietary corn$\operatorname{starch}(\mathrm{P}<0.001)$.

Table 3. Whole-body composition of the soft-shelled turtle fed with different levels of dietary starch

\begin{tabular}{l|c|c|c|c|c|c}
\hline \multirow{2}{*}{ Parameters } & \multicolumn{6}{c}{ Different levels of cornstarch $\left(\mathrm{g} \mathrm{kg}^{-1}\right)$} \\
\cline { 2 - 7 } & 120 & 180 & 240 & 300 & 360 & 420 \\
\hline Moisture (\%) & $84.52 \pm 0.25 \mathrm{a}$ & $81.21 \pm 0.22 \mathrm{~b}$ & $77.58 \pm 0.16 \mathrm{c}$ & $77.96 \pm 0.15 \mathrm{c}$ & $82.16 \pm 0.09 \mathrm{~b}$ & $86.08 \pm 0.21 \mathrm{a}$ \\
Crude proteins & & & & & & \\
$(\%)$ & $10.34 \pm 0.15 \mathrm{c}$ & $13.52 \pm 0.16 \mathrm{~b}$ & $17.08 \pm 0.15 \mathrm{a}$ & $16.98 \pm 0.14 \mathrm{a}$ & $12.92 \pm 0.10 \mathrm{~b}$ & $10.08 \pm 0.10 \mathrm{c}$ \\
Crude lipid & $1.10 \pm 0.03$ & $1.12 \pm 0.04$ & $1.20 \pm 0.05$ & $1.22 \pm 0.03$ & $1.17 \pm 0.03$ & $1.16 \pm 0.05$ \\
$(\%)$ & $4.16 \pm 0.10$ & $4.11 \pm 0.12$ & $4.10 \pm 0.11$ & $4.09 \pm 0.14$ & $4.12 \pm 0.11$ & $4.13 \pm 0.14$ \\
\hline
\end{tabular}

Values are presented as mean \pm S.E (four replications). Statistical significance is indicated by letters. Different letters indicate significant differences; same letters indicate no significant difference. Moisture: $\mathrm{P}=0.035$; crude protein: $\mathrm{P}<0.001$; crude lipid: $\mathrm{P}=0.362$; ash: $\mathrm{P}=0.914$. 
H. Kou et al.

Supplement table: Feed dissolution rate in relation to dietary cornstarch levels

\begin{tabular}{|c|c|c|c|c|c|c|}
\hline \multirow{2}{*}{$\begin{array}{c}\text { Feed } \\
\text { dissolution } \\
\text { rate } \\
(\%)\end{array}$} & \multicolumn{6}{|c|}{ Different levels of cornstarch $\left(\mathrm{g} \mathrm{kg}^{-1}\right)$} \\
\hline & 120 & 180 & 240 & 300 & 360 & 420 \\
\hline $0 \mathrm{~min}$ & 0 & 0 & 0 & 0 & 0 & 0 \\
\hline $10 \mathrm{~min}$ & $2.17 \pm 0.13 \mathrm{a}$ & $2.03 \pm 0.11 \mathrm{a}$ & $1.16 \pm 0.08 \mathrm{~b}$ & $0.45 \pm 0.06 \mathrm{c}$ & $0.39 \pm 0.06 \mathrm{c}$ & $0.26 \pm 0.07 \mathrm{~cd}$ \\
\hline $30 \mathrm{~min}$ & $6.74 \pm 0.72 \mathrm{a}$ & $5.91 \pm 0.71 \mathrm{a}$ & $5.07 \pm 0.59 \mathrm{~b}$ & $3.81 \pm 0.43 \mathrm{c}$ & $3.24 \pm 0.38 \mathrm{~cd}$ & $2.61 \pm 0.39 \mathrm{~d}$ \\
\hline $60 \mathrm{~min}$ & $14.24 \pm 1.26 \mathrm{a}$ & $12.63 \pm 1.18 \mathrm{ab}$ & $10.27 \pm 1.23 \mathrm{~b}$ & $7.42 \pm 1.02 \mathrm{c}$ & $5.21 \pm 0.83 \mathrm{~d}$ & $4.73 \pm 0.65 \mathrm{~d}$ \\
\hline $120 \mathrm{~min}$ & $18.62 \pm 1.89 \mathrm{a}$ & $17.35 \pm 1.84 \mathrm{a}$ & $11.65 \pm 1.43 \mathrm{~b}$ & $8.06 \pm 1.25 \mathrm{c}$ & $6.31 \pm 0.82 \mathrm{~d}$ & $4.95 \pm 0.76 \mathrm{e}$ \\
\hline $300 \mathrm{~min}$ & $29.58 \pm 3.16 \mathrm{a}$ & $28.13 \pm 2.86 \mathrm{a}$ & $24.15 \pm 2.47 \mathrm{ab}$ & $17.43 \pm 2.05 \mathrm{~b}$ & $16.25 \pm 1.83 \mathrm{~b}$ & $13.28 \pm 1.62 \mathrm{c}$ \\
\hline $600 \mathrm{~min}$ & $46.19 \pm 4.02 \mathrm{a}$ & $44.58 \pm 4.05 \mathrm{a}$ & $43.43 \pm 3.68 \mathrm{ab}$ & $36.59 \pm 3.12 \mathrm{~b}$ & $34.68 \pm 2.85 \mathrm{~b}$ & $29.27 \pm 2.63 \mathrm{c}$ \\
\hline
\end{tabular}

Different letters indicate significant differences, same letters indicate no significant difference.

The moisture content in juvenile soft-shelled turtles varied significantly with dietary cornstarch levels $(\mathrm{P}=0.035)$. In contrast to the crude protein, it was the lowest at 240-300 g kg-1 and highest at the lowest and highest dietary cornstarch (Table 3).

No significant response to dietary cornstarch levels was observed for crude lipid (range, 1.10\%-1.21\%) and crude ash (range, 4.09\%-4.16\%) (Table 3).

\section{Digestive enzyme activities}

Protease and $\alpha$-amylase activities are presented in Figure 3 and Figure 4, respectively. The protease activity increased with increasing dietary cornstarch content, but decreased when the cornstarch level was $360 \mathrm{~g} \mathrm{~kg}^{-1}$ or higher. The highest levels were observed at $240-300 \mathrm{~g} \mathrm{~kg}^{-1}$ of dietary cornstarch. The relationship between protease activity and dietary cornstarch level was expressed by a polynomial regression model, as shown in Figure $3\left(y=-0.0014 x^{2}+0.747 x-22.418\left[R^{2}=0.9455\right]\right)$. A secondary curve equation derived from regression analysis of protease activity against the dietary cornstarch level indicated that the optimal dietary cornstarch level for maximum protease activity was $266.79 \mathrm{~g} \mathrm{~kg}^{-1}$.

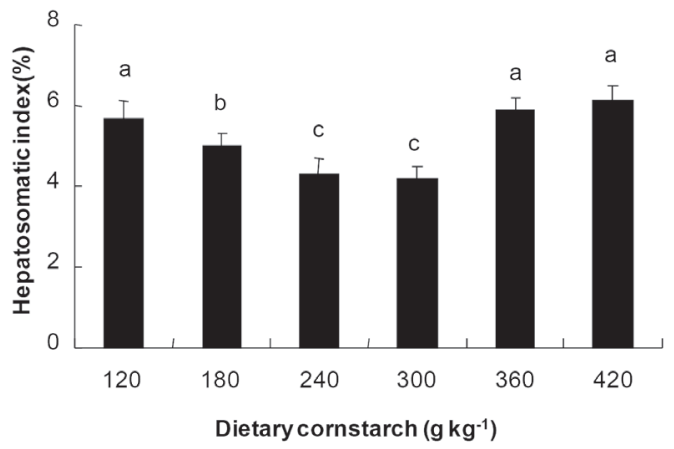

Figure 2. The relationship between hepatosomatic index and dietary cornstarch. Bar chart results are presented as mean \pm SEM $(n=7)$ fish. The lower case letters above the columns indicate significant (between different letters) or non-significant (between same letters) statistical differences. Significance level: between $\mathrm{c}$ and $\mathrm{b}$ or $\mathrm{b}$ and $\mathrm{a}, \mathrm{P}<0.05$; between $\mathrm{c}$ and $\mathrm{a}: \mathrm{P}<0.01$ 


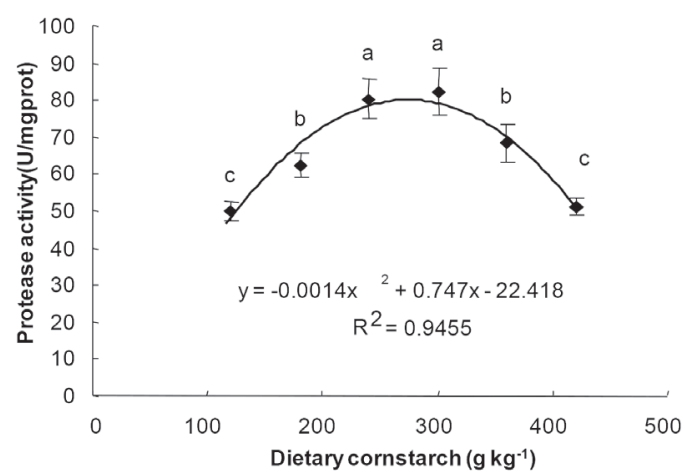

Figure 3. The relationship between protease activity of soft-shelled turtles and dietary cornstarch. A polynomial regression model was obtained. The lower case letters above the columns indicate significant (between different letters) or non-significant (between same letters) statistical differences.

Significance level: between $\mathrm{c}$ and $\mathrm{b}$ or $\mathrm{b}$ and $\mathrm{a}, \mathrm{P}<0.05$; between $\mathrm{c}$ and $\mathrm{a}$ : $\mathrm{P}<0.01$

The $\alpha$-amylase activity had the lowest value when the cornstarch level was 120 $\mathrm{g} \mathrm{kg}^{-1}$, and increased with increasing cornstarch content. It displayed a significant positive correlation with the starch levels (Figure 4).

Lipase activity did not change with dietary cornstarch content (data not shown).

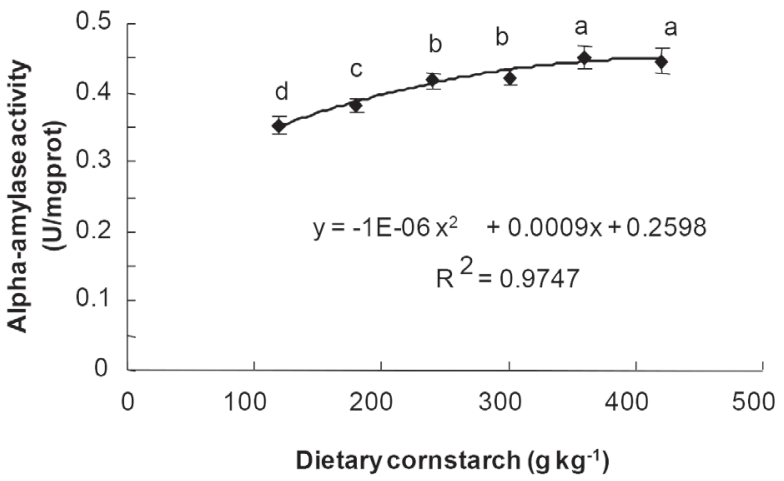

Figure 4. The relationship between alpha-amylase activity and dietary cornstarch. Results are presented as mean \pm SEM $(n=7)$ fish. The lower case letters above the columns indicate significant (between different letters) or non-significant (between same letters) statistical differences Significance level: between $\mathrm{a}$ and $\mathrm{b}$ or $\mathrm{b}$ and $\mathrm{c}$ or $\mathrm{c}$ and $\mathrm{d}, \mathrm{P}<0.05$; between $\mathrm{a}$ and $\mathrm{c}$ or $\mathrm{b}$ and $\mathrm{d}$ : $\mathrm{P}<0.01$; between a and $\mathrm{d}$ :

$$
\mathrm{P}<0.001
$$

\section{Correlation of growth performance and other parameters}

We analyzed the correlation relationship of BWG with other parameters. The $\mathrm{BWG}$ is positively correlated with the survival rate (Figure $5 \mathrm{~A} ; \mathrm{P}<0.001$ ), the crude protein composition (Figure $5 \mathrm{C}$; $\mathrm{P}<0.01$ ), the protease activity (Figure $5 \mathrm{E}$; $\mathrm{P}<0.01$ ); but is negatively correlated with the HSI (Figure $5 \mathrm{~B} ; \mathrm{P}<0.01$ ) and the moisture 
composition (Figure $5 \mathrm{D} ; \mathrm{P}<0.01$ ). No significant correlation is detected between the BWG and the $\alpha$-amylase activity.
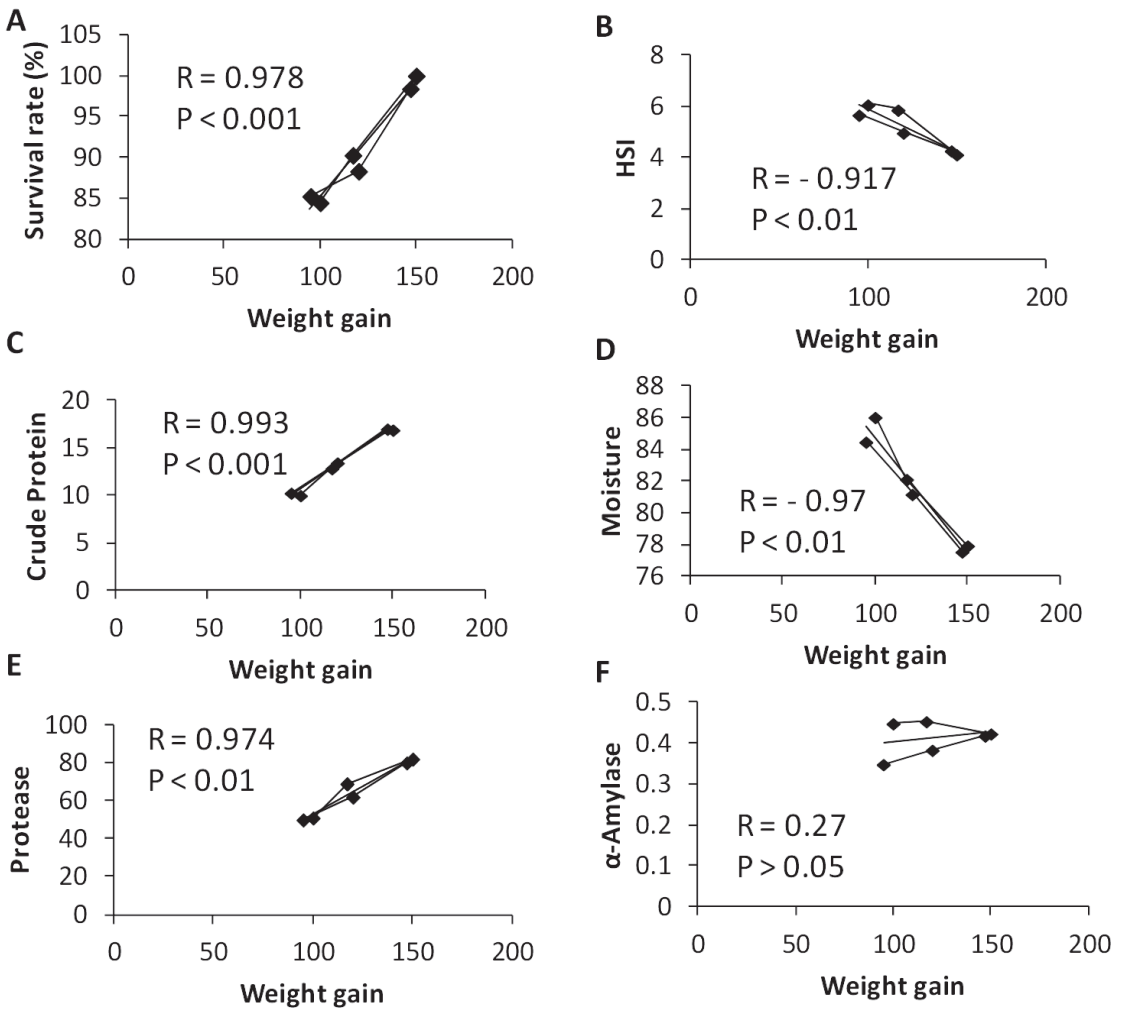

Figure 5. Correlation analyses between BWG and other parameters, such as survival rate (A), HSI (B), crude protein composition (C), moisture composition (D), protease (E) and amylase activities $(\mathrm{F})$. The values of correlation efficiency $(\mathrm{R})$ and significance levels $(\mathrm{P})$ are indicated in the figures

\section{Discussion}

We have, for the first time, examined the influence of dietary starch levels on the growth performance, body composition and the digestive enzymes of the softshelled turtles. The results show that the BWG, the survival rate and the protease activity all changed with the dietary starch levels in a bell-shape like curve, with the highest values at $240-300 \mathrm{~g} \mathrm{~kg}^{-1}$ of starch and lower values at the lower and higher starch levels. The HSI, in contrast, had the lowest values at $240-300 \mathrm{~kg}^{-1}$ of starch levels. In terms of the body composition, the crude protein changed in the same trend as the BWG, while the moisture changed in the opposite direction. It appears that the change of BWG is positively correlated with the change of the crude protein, and negatively correlated with that of the moisture. Moreover, the survival rate also 
increased with the increase in the BWG and the crude protein. Thus, at 240-300 $\mathrm{g}$ $\mathrm{kg}^{-1}$ dietary starch, the turtles had the best growth performance, correlated with an increased crude protein composition in the body.

The changes of protease closely correlated with the growth performance, survival and crude protein, suggesting that the protease activity played an important role in the effects of dietary starch on these functions. It was shown that dietary protease was able to increase the growth performance of piglets, possibly through increasing the digestibility of crude proteins and amino acids (Zuo et al., 2015). Therefore, the appropriate amount of dietary starch may stimulate the secretion of protease, thereby enhancing feed and digestion efficiency and promoting better growth performance.

Past studies have shown that young $P$. sinensis has a high requirement for dietary proteins, with the optimal level of 39-46.5\% (Rawski et al., 2018), while restriction on protein could result in limited growth. Some recent studies, however, suggested that the optimal dietary protein was $33 \%$, while higher levels produced no further benefit on growth (Wang et al., 2014; Zhou C.P. et al., 2013). We adopted this amount of protein in our feeding regime, and show that the growth performance could be further improved by adjusting dietary cornstarch. It is possible that the optimal dietary cornstarch level may produce a protein-sparing effect, but the notion needs to be tested in future experiments.

The $\alpha$-amylase activity increased in a linear correlation to the dietary cornstarch levels. Because it is the direct enzyme for the digestion of carbohydrate, its secretion may be directly stimulated and increased with increasing amount of cornstarch, so that to promote the digestion of the carbohydrate. A study of juvenile Caspian Kutum observed the similar changes of alpha-amylase in relation to dietary carbohydrate levels (Mohammadzadeh et al., 2017). However, the changes of $\alpha$-amylase were not correlated with the changes of growth performance and survivals, so the enzyme may not be directly related to the growth performance and body composition

In reptiles, feeding strategy and diet composition are the main factors for energy utilization. As $P$. sinensis is an omnivorous reptile, carbohydrates can provide up to $50 \%$ of its metabolizable energy (Rawski et al., 2018). Protease and amylase are considered the two main digestive enzymes in the turtle GIT (Sun et al., 2007). The parallel change of protease suggests that the corresponding amount of starch stimulated the secretion of protease and thereby facilitated the digestion of proteins, and hence the enhanced growth performance.

The lipase activity showed no changes in response to different dietary starch levels, suggesting it is neither influenced by dietary starch nor involved in the effects of dietary starch on growth, survival and body composition in P. sinensis.

The optimal starch levels may improve the growth performance and survival through the GIT microbial homeostasis and symbionts. The GIT microbiota may be essential for the secretion of bacterial enzymes and immunological responses, while the disturbance of GIT microbial homeostasis can lead to depressed growth and increased chances of infections (Rawski et al., 2016). Therefore, enhanced immunological resistance to infections may contribute to better health and survival. The microbial GIT symbionts in turtles, on the other hand, can support plant matter digestion and produce SCFAs that are important energy source (Bouchard and 
Bjorndal, 2005). In future, assays of GIT microbial homeostasis and symbionts are warranted to examine their roles in the effects of cornstarch on growth and survivals.

Previous studies have shown the influence of dietary starch on growth performance of other species. For example, the maximum growth rate of whiteleg shrimp (Litopenaeus vannamei) was achieved when fed diets containing $100-200 \mathrm{~g} \mathrm{~kg}^{-1}$ of cornstarch (Guo et al., 2006). It was reported that Procambarus clarkii fed diets containing $200 \mathrm{~g} \mathrm{~kg}^{-1}$ of cornstarch had the best growth performance and feed utilization. When dietary carbohydrate levels exceed an optimum, animals cannot undergo a further increment in growth (Xiao et al., 2014). The growth rate of white sturgeon (Acipenser transmontanus) fed hydrolyzed potato starch (HPS)-15 and -30 was higher than fish fed control diets (Deng et al., 2005). In some species, however, no growth improvement was observed with adding starch. For example, it was reported that neither level (100 or $200 \mathrm{~g} \mathrm{~kg}^{-1}$ ) nor nature (raw or waxy) of starch had measurable effects on growth performance and feed utilization in juvenile European sea bass (Enes et al., 2006). Similar results have been reported in juvenile Atlantic salmon, Salmo salar (Hemre et al., 2000).

Reports have indicated that the dietary starch level is an important factor in regulation of carbohydrate metabolism in gilthead sea bream juveniles. Dietary starch enhanced liver glycolytic and lipogenic pathways, while depressing protein catabolism (Enes et al., 2008). The dietary starch level may negatively affect carbohydrate digestibility and may also interact with the digestibility of other dietary constituents (Stone et al., 2003). The presence of the digestive enzymes, $\alpha$-amylase and $\alpha$-glycosidase, is sufficient to hydrolyze starch to glucose, thus making glucose available for transport and metabolism (Cuzon et al., 2000). The ability to digest starch varies among fish species. It is generally thought that coldwater fish has a lower capacity to digest and utilize raw starch than warm-water herbivorous or omnivorous fish (Hemre et al., 2002). Salmonids have a limited capability to digest and utilize crude starch. Similar results were observed in our experiments. Soft-shelled turtles are categorized as carnivorous fish. Excess $\alpha$-starch in feed may depress digestibility and decrease growth. Consistent with our findings, it was found that $330 \mathrm{~g}$ $\mathrm{kg}^{-1}$ of dietary carbohydrates limited the growth of Litopenaeus stylirostris juveniles (Rosas et al., 2000). However, there are some contradictory reports. For example, sea bass is strictly carnivorous, but the species can be fed large amount of plant carbohydrates. The diet of sea bass can contain at least $250 \mathrm{~g} \mathrm{~kg}^{-1}$ starch without detrimental effect (Gatesoupe et al., 2014). The authors attributed this phenomenon to different species.

The change of HSI was in reverse correlation with the BWG. A reduced HSI of fish has been considered as an indicator of contaminant stress, but not reliable (Yang and Baumann, 2006). A number of studies showed that fish from chemically contaminated sites had elevated HSI compared to fish from relatively uncontaminated sites (Everaarts et al., 1993; Pinkney et al., 2001). The liver size could be influenced by a variety of factors other than contaminants as well (Fabacher et al., 1988). In our controlled experimental conditions, contamination is less probable. The reason and the significance that the liver weight did not increase with the body weight remain to be determined. 
The survival rate changed in relation to the dietary starch ratios in the same trend as the BWG. This observation is different from the results reported for P. clarkii (Xiao et al., 2014) and L. vannamei (Rosas et al., 2001), these animals showed decreasing survival with increasing dietary $\alpha$-starch levels. The different results may be attributable to species differences.

The optimum lipid level of the diet was shown to be $80-90 \mathrm{~g} \mathrm{~kg}^{-1}$ (Huang et al., 2005), so we designed the formulation to assure the lipid was suitable for a practical diet. No clear variation pattern with dietary cornstarch was observed for crude lipid (range, $1.10 \%-1.21 \%$ ) and crude ash in the turtle. Our results are in agreement with studies reported in other species, such as rainbow trout (Oncorhynchus mykiss) (Alvarez et al., 1999), European sea bass (Dicentrarchus labrax) (Enes et al., 2006) and gilthead sea bream (Sparus aurata) (Enes et al., 2008; Peres and Oliva-Teles, 2002). No effect of dietary carbohydrate on whole body composition was observed in these species. The nutrient gain and whole body composition $\left(180 \mathrm{~g} \mathrm{~kg}^{-1}\right.$ protein and $130 \mathrm{~g} \mathrm{~kg}^{-1}$ lipid) of black spot sea bream were not affected by corn starch type (CS and GS) or dietary protein levels (450 and $350 \mathrm{~g} \mathrm{~kg}^{-1}$ ) (Figueiredo-Silva et al., 2009).

In conclusion, our data show that appropriate dietary starch levels can have a positive impact on the growth performance, body composition and digestive enzyme activities of the soft-shelled turtle. We show that the optimal dietary starch content of $240-300 \mathrm{~g} \mathrm{~kg}^{-1}$ in practical diets can produce the best growth performance of juvenile soft-shelled turtles.

Turtles are omnivorous, appropriate levels of dietary plant matters (e.g., duckweed), probiotics, and other components may produce positive effect on the growth performance (Bouchard and Bjorndal, 2006; Rawski et al., 2016). Expanding the production of soft-shelled turtle by adding or adjusting these dietary components is therefore worthy of further investigation.

\section{Disclosure}

The authors declare that there is no conflict of interest.

\section{References}

Alvarez M.J., López-Bote C.J., Diez A., Corraze G., Arzel J., Dias J., Kaushik S.J., B a ut is t a J.M. (1999). The partial substitution of digestible protein with gelatinized starch as an energy source reduces susceptibility to lipid oxidation in rainbow trout (Oncorhynchus mykiss) and sea bass (Dicentrarchus labrax) muscle. J. Anim. Sci., 77: 3322-3329.

AOAC International Methods Committee (2011). AOAC INTERNATIONAL Methods Committee guidelines for validation of biological threat agent methods and/or procedures. J AOAC Int, 94: $1359-81$.

B o u ch ard S.S., B jor nd a 1 K.A. (2005). Microbial fermentation in juvenile and adult pond slider turtles, Trachemys scripta. J. Herpetology, 39: 321-324 (doi: 10.1670/145-04N).

B o u ch ard S.S., B j ornd a 1 K.A. (2006). Nonadditive interactions between animal and plant diet items in an omnivorous freshwater turtle Trachemys scripta. Comp. Biochem. Physiol. B Biochem. Mol. Biol., 144: 77-85.

Chu J.-H., Chen S.-M., Huang C.-H. (2007). Effect of dietary iron concentrations on growth, 
hematological parameters, and lipid peroxidation of soft-shelled turtles, Pelodiscus sinensis. Aquaculture, 269: 532-537.

Cuzon G., Ros as C., Gaxi ola G. (2000). Utilization of carbohydrates by shrimp. In: Avances en Nutrición Acuícola V. Memorias del V Simposium Internacional de Nutrición Acuícola, Cruz-Suárez L.E. et al. (eds). 19-22 Noviembre, pp. 328-339.

D e m p s on J., S chwarz C., S he ars M., F u re y G. (2004). Comparative proximate body composition of Atlantic salmon with emphasis on parr from fluvial and lacustrine habitats. J. Fish Biol., 64: $1257-1271$.

D e ng D.-F., H e m re G.-I., S to r e b a k k en T., S h i a u S.-Y., H ung S.S.O. (2005). Utilization of diets with hydrolyzed potato starch, or glucose by juvenile white sturgeon (Acipenser transmonta$n u s)$, as affected by Maillard reaction during feed processing. Aquaculture, 248: 103-109.

En e s P., P a n s e r at S., K a u s hik S., O liv a - Te le s A. (2006). Effect of normal and waxy maize starch on growth, food utilization and hepatic glucose metabolism in European sea bass (Dicentrarchus labrax) juveniles. Comp. Biochem. Physiol. A: Mol. Integr. Physiol., 143: 89-96.

Enes P., P a n s erat S., K a u shik S., O liva-Teles A. (2008). Growth performance and metabolic utilization of diets with native and waxy maize starch by gilthead sea bream (Sparus aurata) juveniles. Aquaculture, 274: 101-108.

E ver a art s J.M., S hug a rt L.R., Gu st in M.K., H a w kin s W.E., Wa 1 k e r W.W. (1993). Biological markers in fish: DNA integrity, hematological parameters and liver somatic index. Marine Environ. Res., 35: 101-107.

F a b a cher D.L., S chmit t C.J., B e s s e r J.M., M a c M.J. (1988). Chemical characterization and mutagenic properties of polycyclic aromatic compounds in sediment from tributaries of the great lakes. Environ. Toxicol. Chem., 7: 529-543.

F e n g H., M a t s u k i N., S a i t o H. (1996). Improvement of fatigue and acceleration of recovery from stress-induced deficient sexual behavior in mice following oral administration of soft-shelled turtle powder. Biol. Pharm. Bull., 19: 1447-50.

Figueiredo-Silva A.C., Corraze G., Rema P., S anchez-Gurmaches J., Gutiérre z J., Va l e n te L.M.P. (2009). Blackspot seabream (Pagellus bogaraveo) lipogenic and glycolytic pathways appear to be more related to dietary protein level than dietary starch type. Aquaculture, 291: 101-110.

Gatesoupe F.-J., Huelvan C., Le B yon N., S évère A., A a sen I.M., D egnes K.F., Mazura is D., P an serat S., Z a mbonino-In fante J.L., K a u shik S.J. (2014). The effects of dietary carbohydrate sources and forms on metabolic response and intestinal microbiota in sea bass juveniles, Dicentrarchus labrax. Aquaculture, 422-423: 47-53.

Gong S., Vamberger M., A uer M., Praschag P., Fritz U. (2018). Millennium-old farm breeding of Chinese softshell turtles (Pelodiscus spp.) results in massive erosion of biodiversity. Naturwissenschaften, 105: 34.

G u o R., Li u Y.J., Tian L.X., H u ang J.W. (2006). Effect of dietary cornstarch levels on growth performance, digestibility and microscopic structure in the white shrimp, Litopenaeus vannamei reared in brackish water. Aquacul. Nutr., 12: 83-88.

H a it a o S., P a rh a m J.F., Z h i y ong F., M e i l ing H., F eng Y. (2008). Evidence for the massive scale of turtle farming in China. Oryx, 42: 147-150.

He mre G.I., Shiau S.Y., Deng D.F., S torebakken T., Hung S.S.O. (2000). Utilization of hydrolysed potato starch by juvenile Atlantic salmon Salmo salar L., when using a restricted feeding regime. Aquacul. Res., 31: 207-212.

Hem re G.I., Mommsen T.P., Krogdahl $\AA$. (2002). Carbohydrates in fish nutrition: effects on growth, glucose metabolism and hepatic enzymes. Aquacul. Nutr., 8: 175-194.

$\mathrm{H}$ u a n g C.H., L in W.Y. (2002). Estimation of optimal dietary methionine requirement for softshell turtle, Pelodiscus sinensis. Aquaculture, 207: 281-287.

H u an g C.H., Lin W.Y., Ch u J.H. (2005). Dietary lipid level influences fatty acid profiles, tissue composition, and lipid peroxidation of soft-shelled turtle, Pelodiscus sinensis. Comp. Biochem. Physiol. A, Mol. Integr. Physiol., 142: 383-8.

Kannadhas on S., Muthukumarappan K., Ros entrater K.A. (2009). Effects of ingredients and extrusion parameters on aquafeeds containing DDGS and tapioca starch. J. Aquacul. Feed Sci. Nutr., 1: 6-21. 
K a w a i S.-I., I k e d a S. (1972). Studies on digestive enzymes of fishes - II: Effect of dietary change on the activities of digestive enzymes in carp intestine. NIPPON SUISAN GAKKAISHI, 38: $265-270$.

L e i S.-J. (2006). Effects of ration level and feeding frequency on digestibility in juvenile soft-shelled turtle, Pelodiscus sinensis. J. Zhejiang Univ. Sci. B, 7: 580-585.

L in W.Y., H u a g C.H. (2007). Fatty acid composition and lipid peroxidation of soft-shelled turtle, Pelodiscus sinensis, fed different dietary lipid sources. Comp. Biochem. Physiol. Toxicol. Pharmacol. CBP, 144: 327-33.

Mazurkiewicz J., Przybył A., Czyżak-Runowska G., Lyczyński A. (2011). Coldpressed rapeseed cake as a component of the diet of common carp (Cyprinus carpio L.): effects on growth, nutrient utilization, body composition and meat quality. Aquacul. Nutr., 17: 387-394.

Moham madzadeh S., Noverian H.A., Ouraji H., Fal ah a tkar B. (2017). Growth, body composition and digestive enzyme responses of Caspian Kutum, Rutilus frisii (Kamenskii, 1901), juveniles fed different levels of carbohydrates. J. Applied Ichthyol., 33: 983-990 (doi: 10.1111/ jai.13411).

P e res H., O liva - Teles A. (2002). Utilization of raw and gelatinized starch by European sea bass (Dicentrarchus labrax) juveniles. Aquaculture, 205: 287-299.

P in kn e y A.E., H a r shbarger J.C., M y E.B., M e l a n c on M.J. (2001). Tumor prevalence and biomarkers of exposure in brown bullheads (Ameiurus nebulosus) from the tidal Potomac River, USA, watershed. Environ. Toxicol. Chem., 20: 1196-205.

Raw ski M., Ki erończyk B., Długosz J., Św iątkiewicz S., Józefiak D. (2016). Dietary probiotics affect gastrointestinal microbiota, histological structure and shell mineralization in turtles. PLoS One, 11: e0147859.

Rawski M., Mans C., Kierończyk B., Świątkiewicz S., Barc A., Józefiak D. (2018). Freshwater turtle nutrition - a review of scientific and practical knowledge. Ann. Anim. Sci, 18: 17-37.

Ren M., A i Q., Mai K., Ma H., Wang X. (2011). Effect of dietary carbohydrate level on growth performance, body composition, apparent digestibility coefficient and digestive enzyme activities of juvenile cobia, Rachycentron canadum L. Aquacul. Res., 42: 1467-1475 (doi: 10.1111/j.13652109.2010.02739.x).

R i a z M.N. (1997). Using extrusion to make floating and sinking fish feed: Controlling the water stability of feed. Feed Mgmt, 46: 21-24.

Rosas C., Cuzon G., Gaxiola G., Arena L., Lemaire P., Soyez C., Van Wormh o u d t A. (2000). Influence of dietary carbohydrate on the metabolism of juvenile Litopenaeus stylirostris. J. Exp. Marine Biol. Ecol., 249: 181-198.

Ros a s C., Le Priol Y., Contreras F., Cuzon G., P a s cual C., S a n chez A., Gaxiola G. (2001). Metabolism and growth of juveniles of Litopenaeus vannamei: effect of salinity and dietary carbohydrate levels. J. Exp. Marine Biol. Ecol., 259: 1-22.

S h a o Q. (2012). Soft-shelled Turtles. In: Aquaculture, 2nd Edition, Lucas J.S., Southgate P.C. (eds). Blackwell Publishing Ltd., West Sussex, UK, pp. 460-475.

S o 1 o m o n S.G., A t a g u b a G.A., A b e j e A. (2011). Water stability and floatation test of fish pellets using local starch sources and yeast (Saccharomyces cerevisae). International J. Latest Trends in Agriculture and Food Sciences, 1: 1-5.

Stone D.A.J., A 11 an G.L., Anders on A.J. (2003). Carbohydrate utilization by juvenile silver perch, Bidyanus bidyanus (Mitchell). III. The protein-sparing effect of wheat starch-based carbohydrates. Aquacul. Res., 34: 123-134.

Tran-Duy A., S m it B., van D a m A.A., S chram a J.W. (2008). Effects of dietary starch and energy levels on maximum feed intake, growth and metabolism of Nile tilapia, Oreochromis niloticus. Aquaculture, 277: 213-219.

Wang J., Qi Z., Yang Z. (2014). Evaluation of the protein requirement of juvenile Chinese soft-shelled turtle (Pelodiscus sinensis, Wiegmann) fed with practical diets. Aquaculture, 433: $252-255$.

Wang W., L i C.Y., G e C.T., L e i L., Gao Y.L., Q i a n G.Y. (2013). De-novo characterization of the soft-shelled turtle Pelodiscus sinensis transcriptome using Illumina RNA-Seq technology. J Zhejiang Univ. Sci. B, 14: 58-67. 